\title{
Cellulosic hydrolysate toxicity and tolerance mechanisms in Escherichia coli
}

\author{
Tirzah Y Mills ${ }^{\dagger}$, Nicholas R Sandoval ${ }^{\dagger}$ and Ryan T Gill*
}

\author{
Address: Department of Chemical and Biological Engineering, UCB424/ECCH120, University of Colorado, Boulder, CO 80309, USA \\ Email: Tirzah Y Mills - tirzah.mills@colorado.edu; Nicholas R Sandoval - nicholas.sandoval@colorado.edu; Ryan T Gill* - rtg@colorado.edu \\ * Corresponding author †Equal contributors
}

Published: 15 October 2009

Biotechnology for Biofuels 2009, 2:26 doi:10.1186/1754-6834-2-26
Received: 25 June 2009

Accepted: 15 October 2009

This article is available from: http://www.biotechnologyforbiofuels.com/content/2/1/26

(c) 2009 Mills et al; licensee BioMed Central Ltd.

This is an Open Access article distributed under the terms of the Creative Commons Attribution License (http://creativecommons.org/licenses/by/2.0), which permits unrestricted use, distribution, and reproduction in any medium, provided the original work is properly cited.

\begin{abstract}
The sustainable production of biofuels will require the efficient utilization of lignocellulosic biomass. A key barrier involves the creation of growth-inhibitory compounds by chemical pretreatment steps, which ultimately reduce the efficiency of fermentative microbial biocatalysts. The primary toxins include organic acids, furan derivatives, and phenolic compounds. Weak acids enter the cell and dissociate, resulting in a drop in intracellular $\mathrm{pH}$ as well as various anion-specific effects on metabolism. Furan derivatives, dehydration products of hexose and pentose sugars, have been shown to hinder fermentative enzyme function. Phenolic compounds, formed from lignin, can disrupt membranes and are hypothesized to interfere with the function of intracellular hydrophobic targets. This review covers mechanisms of toxicity and tolerance for these compounds with a specific focus on the important industrial organism Escherichia coli. Recent efforts to engineer $E$. coli for improved tolerance to these toxins are also discussed.
\end{abstract}

\section{Introduction}

Governments around the world are calling for increased production of renewable transportation fuels in light of massive increases in energy consumption [1-5]. The United States has mandated the production of 36 billion gallons of biofuels by 2022, with even greater increases of up to 60 billion gallons by 2030 proposed by the new administration $[1,6]$. A major challenge is that current production methods based on corn ethanol are limited to 10 to 15 billion gallons per year [7]. Moreover, corn ethanol has recently come under criticism for its potential to increase greenhouse gas emissions when compared to fossil fuels and negative impact on food markets [8-10]. These findings stipulate that new feedstocks and processes capable of producing 20 to 50 billion gallons per year, while not increasing greenhouse gas emissions, must be responsibly developed and commercialized within the next two decades. Biofuels derived from lignocellulosic biomass hold promise for making up a significant fraction of this market.

Lignocellulosic feedstocks, such as switchgrass, poplar, and corn stover, provide greenhouse gas savings of 65 to $100 \%$ in comparison to petrol [11]. When land-use changes are considered, cellulosic ethanol still has the ability to reduce overall greenhouse gas emissions depending on the source of biomass and associated landuse change [8]. Feedstocks that do not require a substantial change in land-use include crop and municipal wastes, fall grass harvests, and algae [8]. Other potential feedstocks include waste from pulp and paper mills, construction debris, and animal manures [1]. These feedstocks are of extreme interest because they require no additional land-use conversion [8]. 
Many processes exist and have been recently reviewed for the pretreatment of lignocellulosic biomass to produce a fermentable hydrolysate [12-16]. The overall goal of pretreatment is to better expose cellulose for downstream hydrolysis, convert hemicellulose to pentoses, and to remove lignin [13].

Harsh conditions used in pretreatment create a variety of toxic compounds that inhibit the fermentation performance. Inhibitors have been categorized previously by Olsson and Hahn-Hägerdal [17]. Specifically, acetic acid is released from acetylxylan decomposition, furan derivatives result from sugar dehydration, and phenolic compounds are derived from lignin. Furan derivatives include 2-furaldehyde (furfural) and 5-hydroxymethylfurfural (HMF), which result from pentose and hexose dehydration, respectively $[18,19]$. Subsequent degradation of furfural and HMF introduces formic acid and levulinic acid, respectively, into the hydrolysate. Phenolic compounds of interest include acids, alcohols, aldehydes, and ketones [20]. Metallic cation levels have measurable variance depending on the pretreatment method, but levels are low enough to not significantly affect fermentation [21].

Although many fermentative microorganisms exist, Escherichia coli, Saccharomyces cerevisiae, and Zymomonas mobilis are the most promising industrial biocatalysts for biofuels production [22]. Each microorganism has limitations in native substrate utilization, production capacity, or tolerance. Unlike S. cerevisiae or Z. mobilis, E. coli natively ferments both hexose and pentose sugars. Ethanologenic E. coli also has higher tolerance to lignocellulosic inhibitors than its fermentative counterparts [23-25]. In 2007, Jarboe et al. [26] compared ethanol production between these three microorganisms, determining that $E$. coli is comparable with or surpasses other reported production levels, despite its low membrane tolerance to ethanol. These qualities along with advanced knowledge about the E. coli genome and regulation make this bacterium a prime candidate for further development.

As depicted in Figure 1, generally accepted categories of antimicrobial activity for inhibitors in lignocellulosic hydrolysate include: compromising the cell membrane; inhibiting essential enzymes; or negative interaction with DNA or RNA [27-32]. These compounds often act by inhibiting multiple targets. Although efforts are underway to limit the amount and types of inhibitors created during pretreatment, at the present time, economically viable processes still fall short. Regardless of pretreatment optimization, inhibitors such as acetic acid, released directly from hemicellulose decomposition, will remain in the hydrolysate. Thus, the need to engineer more tolerant fermentative microorganisms exists. In this work, known modes of toxicity and tolerance pertaining to E. coli and lignocellulosic inhibitors will be reviewed, in addition to new technologies that are aimed at engineering the bacterium for fermentation of lignocellulosic biomass.

\section{Organic acids}

Organic acids derived from lignocellulosic biomass pretreatment and subsequent saccharification inhibit the growth and metabolism of E. coli. This, in turn, reduces the yield, titer, and productivity of biofuel fermentation. Various organic acids are created in pretreatment steps: acetic acid is derived from the hydrolysis of acetylxylan, a main component of hemicellulose; others (formic, levulinic, and so on) are result from degraded sugars [33].

Acetic acid is usually found at the highest concentration in the hydrolysate [34-40]. Levels of acetate depend on the type of cellulosic biomass and the pretreatment method. Concentrations typically range from 1 to $>10 \mathrm{~g} / \mathrm{L}$ in the hydrolysate. Formic acid, while more toxic to E. coli than acetic acid, is typically present at concentrations much less than that of acetic acid (commonly a tenth of acetic acid concentrations) $[23,35,36]$. Other toxic weak acids, whose hydrolysate concentrations are rarely reported, are present at an even lower concentration than formic acid $[35,37,38,41]$.

\section{Modes of toxicity}

Weak organic acids have been shown to primarily inhibit the production of cell mass, but not the fermentation itself [23]. Acetate is the most studied organic acid inhibitor in E. coli. Acetate is a natural fermentation product that is known to accumulate due to 'overflow metabolism' and inhibit cell growth. Acetate concentrations as low as $0.5 \mathrm{~g} / \mathrm{L}$ have been shown to inhibit cell growth by $50 \%$ in minimal media [42,43]. However, in E. coli KO11, concentrations of acetate up to $12 \mathrm{~g} / \mathrm{L}$ did not significantly affect ethanol yield, although ethanol titer decreased with high levels of acetate [44]. Attempts have been made to mathematically describe the relationship between growth rate and acetate concentration, with varying results. Koh et al. [45] proposed the following equation for specific growth $(\mu)$ in a batch reactor:

$$
\frac{\mu}{\mu_{\max }}=\frac{1}{1+k \cdot[A c]}
$$

The value of the constant, $k$, ranged from $0.125 \mathrm{~L} / \mathrm{g}$ to $0.366 \mathrm{~L} / \mathrm{g}$ depending on the strain and media [45]. Luli and Strohl [46] reported an exponential decay model of inhibition:

$$
\frac{\mu}{\mu_{\max }}=e^{-k \cdot[A c]}
$$




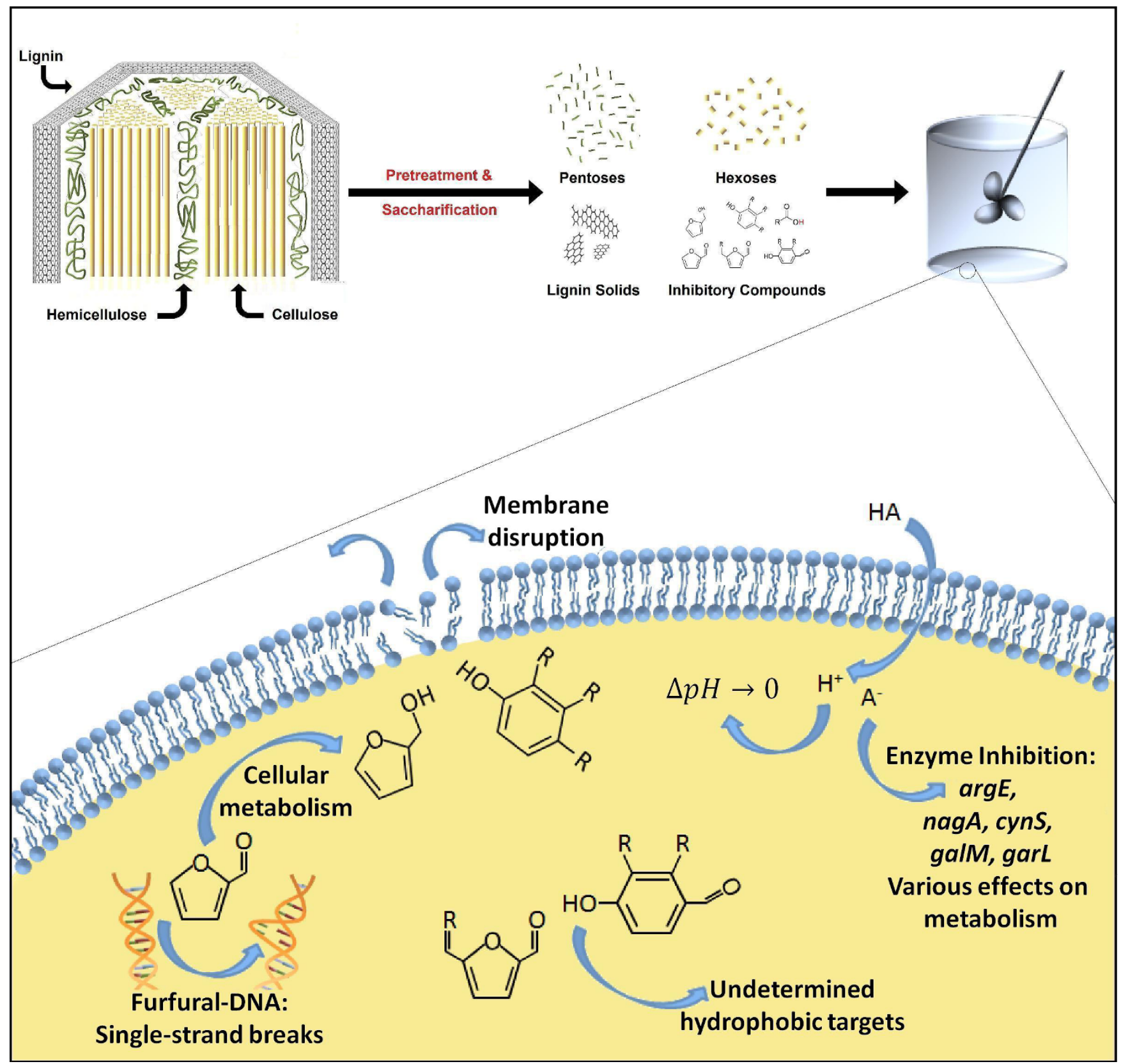

\section{Figure I}

Hydrolysate inhibitors. Lignocellulosic biomass is processed into component sugars, lignin solids, and inhibitory compounds. These inhibitors can affect microbial growth in various ways, including DNA mutation, membrane disruption, intracellular $\mathrm{pH}$ drop, and other cellular targets.

The value of the constant was calculated as $0.06 \mathrm{~L} / \mathrm{g}$ of acetate. In both shake flasks and a fermentor, Nakano et al. [47] report a linear inhibition trend. Specific growth rates in shake flasks were four times as low for any given concentration of acetate compared to the fermentor. This difference in toxicity was attributed to the controlled dissolved oxygen in the fermentor. The $\mathrm{IC}_{50}$, the concentration of acetate that inhibits growth by $50 \%$, ranges from 2.75 to $8 \mathrm{~g} / \mathrm{L}$ depending on the strain and media $[23,45,46]$.

Weak acids in the undissociated form can permeate the cell membrane, and, once inside, dissociate to release the anion and the proton. These 'uncoupling agents' disrupt the transmembrane $\mathrm{pH}$ potential since, effectively, a proton is allowed across the membrane without the creation 
of ATP [48]. This dissociation of the weak acid inside the cytoplasm is due to the fact the intracellular $\mathrm{pH}, \mathrm{pH}_{i}$, is naturally at a $\mathrm{pH}$ of approximately 7.8 , which is much higher than the weak acid's $\mathrm{pK}_{a}[42]$. As these acids dissociate inside the cell, the $\mathrm{pH}_{i}$ decreases, which can inhibit growth [42]. External pH has a large affect on the toxicity of the weak acids. E. coli KO11 in LB media with $5.0 \mathrm{~g} / \mathrm{L}$ acetate reached an ethanol titer twice as fast at an initial $\mathrm{pH}$ of 7.0 compared to initial $\mathrm{pH}$ of 6.0 , and thrice as fast compared to an initial pH of 5.5 [44]. When E. coli LY01 was subjected, at a starting $\mathrm{pH}$ of 6.0 , to acetic, formic, or levulinic acid at the $\mathrm{IC}_{50}$ obtained at a neutral $\mathrm{pH}$, the growth rate decreased to $0 \%, 35 \%$, and $10 \%$, respectively, that of control growth [23]. Formic acid may be more toxic due to the fact it has an extraordinarily high permeability through the membrane [49]. This external $\mathrm{pH}$ effect is due, in part, to the fact that the acid exists in its undissociated form at higher concentrations, allowing for higher permeation of the cell membrane.

The anion also has an inhibitory effect. The anion accumulates inside the cell, which can affect the cell turgor pressure [42]. Inhibition has been shown to be anion specific $[23,42,43]$. When $E$. coli inhibition from acetate was compared to benzoate, the same growth rate was observed for differing $\mathrm{pH}_{i}$ (7.26 for benzoate and 7.48 for acetate) [42]. Zaldivar and Ingram [23] reported that the toxicity of weak acids depended highly on the hydrophobicity of the acid.

The modes of toxicity of weak acids are not easily elucidated. Formic and propionic acid have been shown to inhibit the synthesis of macromolecules, as the cells stop growing after addition of the acids [50]. More so than other macromolecules, DNA synthesis was slowed [50]. DNA repair-deficient strains were shown to be more sensitive to weak acids when tested in stationary phase [51]. However, repair deficient strains were not overly sensitive to organic acids in growth phase [52]. This, plus the lack of an observed SOS response, suggests that the DNA was not damaged by these acids [52]. The hypothesis of membrane disruption has also been investigated. Leakage of cell contents in the presence of weak organic acids was small when compared to the leakage associated with a membrane disrupting antibiotic (polymyxin B) or even ethanol, and thus is not likely to be the primary cause of weak acid inhibition $[23,53]$. Weak acids have been shown to reduce the intracellular pools of some amino acids. Glutamate and aspartate, precursors to many different amino acids, were shown to be at a significantly lower concentration in the cytoplasm when $E$. coli was grown in the presence of weak acid [42]. Glutamate has been shown to be important during growth as a protective osmolyte [54,55]. Lysine, arginine, glutamine, and methionine were also found at lower concentrations when incubated with weak acid $[42,43]$. The addition of methionine to the incubation mixture has been shown to alleviate much of the toxicity associated with acetate [43].

\section{Modes of tolerance}

E. coli acid resistance mechanisms are thought to increase E. coli survival when passing through the low $\mathrm{pH}$ environment in the stomach. It has long been known that cells can sense and regulate intracellular $\mathrm{pH}$ [56]. Also, it has been shown that treatment of bacteria to moderately low levels of $\mathrm{pH}$ (5.0) before exposure to very low $\mathrm{pH}$ (3.0 to 3.5 ) increases the tolerance more than 50-fold [57].

E. coli naturally has several known mechanisms to combat acid stress. One mechanism for acid tolerance requires the presence of an amino acid decarboxylase coupled with an antiporter that exports the decarboxylated product and imports the amino acid used [58-60]. It is widely thought that the tolerance is due to the fact that the decarboxylation and antiporter reactions consume and export one intracellular proton across the cell membrane. This raises the $\mathrm{pH}_{i}$ of the cell, which is beneficial for survival and growth [58-62]. The transmembrane potential is also affected by these acid resistance mechanisms. E. coli, which normally has a negative transmembrane potential, had a positive potential during acid stress when either the arginine- or glutamine-dependent systems were activated. This mimics what is seen in acidophiles [61]. These mechanisms of tolerance have also been reviewed and depicted by Warnecke et al. [63].

All acid resistance mechanisms, however, are not equally effective. The glutamate-dependent acid resistance mechanism is the most studied and the most robust, the arginine-dependent mechanism provides a moderate level of resistance, and the lysine-dependent mechanism confers a minimal level of tolerance [59-62,64,65]. The levels of tolerance are highly dependent on the strain, treatment before shock, the media used, growth phase, and the strength and length of acid stress [58-62,64,65]. The differences in efficacy between the mechanisms may lie in the optimal $\mathrm{pH}$ for the amino acid decarboxylase. The optimum pHs for the glutamate, arginine, and lysine decarboxylases are 4,5, and 5.7, respectively [61]. The lower the optimal pH of the enzyme, the more efficient it is during times of acid stress.

These acid resistance mechanisms have complicated regulation. Low $\mathrm{pH}$ can induce heat and oxidative shock regulons, genes coding for membrane-proteins, and acid consumption [66]. It is known that the rpoS regulon is induced by exposure to weak acids $[64,67,68]$. Once induced, the $r p o S$ response leads to higher survival rates at low $\mathrm{pH}$, oxidative stress, and heat stress [68]. However, the $r p o S$ response alone is not sufficient for acid tolerance. 
Cultures exposed to $\mathrm{NaCl}$, which also induced the rpoS response, failed to increase acid survival [68]. RpoS has also been implicated in glutamine-dependent acid resistance [62]. This system has been shown to have at least two sigma factors $\left(\sigma^{\mathrm{S}}\right.$ and $\left.\sigma^{70}\right)$ and at least five regulatory proteins (encoded by crp, ydeO, gadE, gadX, and gadW) involved in the expression of the decarboxylases ( $\mathrm{gadA}$ and $B$ ) and the antiporter ( $g a d C)$ [69-71].

Other modes of tolerance to weak acids are also known. DNA stabilization via Dps protein interactions has been shown to be beneficial at low $\mathrm{pH}$ [72]. Acetate treatment was shown to increase expression of many other genes; these genes are mostly involved in general metabolism of the cell as well as in outer membrane protein production [68]. In a genomic library selection with 3-hydroxyproionic acid, genes coding for inner membrane proteins and certain genes involved in cell metabolism were found to be most enriched $[73,74]$.

\section{Furan derivatives}

Furan derivatives are a result of sugar dehydration during pretreatment. Furfural and HMF are the primary derivatives appearing in lignocellulosic hydrolysate. Concentrations typically range between 0 and $5 \mathrm{~g} / \mathrm{L}$ for each compound $[20,21,75,76]$. As previously mentioned, levulinic and formic acid are also formed via degradation of these aldehydes [77]. While dilute acid hydrolysis is a common method for pretreatment, acidic conditions are known to cause dehydration of a small fraction of the sugar monomers. Hemicellulose is the second most abundant renewable polysaccharide, averaging 25 to $35 \%$ of viable lignocellulosic biomass composition [78]. Therefore, processes that avoid degradation of the $\mathrm{C}_{5}$ and $\mathrm{C}_{6}$ monomers are vital. While new methods are being developed to reduce the amount of furfural and HMF formed during pretreatment [79-81], industrial-scale technology and knowledge about process kinetics currently favors more traditional processes like dilute sulfuric acid treatment $[34,82,83]$. Therefore, it is important to improve understanding of the genetic and metabolic mechanisms underlying tolerance to furan derivatives.

Aldehydes in general are known to have detrimental effects in microorganisms. For example, Haselkorn and Doty [84] showed that formaldehyde denatures and interacts with polynucleotides. Formaldehyde is also known to cause protein-protein cross-linking [85]. In vitro experiments with crude cell extracts identified a glutathionedependent formaldehyde dehydrogenase that is responsible for conferring aldehyde tolerance [86]. Two previously uncharacterized proteins, FrmB and YeiG, have also been identified for their role in conferring folrmaldehyde tolerance via a glutathione-dependent formaldehyde hydrolysis pathway [87]. Besides enzymatic detoxification, outer membrane protein composition has also been indicated as conferring increased tolerance to formaldehyde, acetylaldehyde, and glutaraldehyde [88]. Furthermore, methylgloxal, a dicarbonyl compound, has been shown to inhibit $E$. coli growth and protein synthesis at concentrations of $0.07 \mathrm{~g} / \mathrm{L}[89,90]$. We will focus here on the two primary aldehyde compounds found in the hydrolysate, furfural and HMF.

\section{Modes of toxicity}

Furfural has been identified as a key inhibitor in lignocellulosic hydrolysate because it is toxic by itself and also acts synergistically with other inhibitors [24]. Hydrophobicity is a marker of an organic compound's toxicity. Highly hydrophobic compounds have been shown to compromise membrane integrity [29]. Interestingly, perceptible membrane damage in E. coli resulting from furfural exposure has not been observed, despite a known $\log \left(\mathrm{P}_{\text {octanol/ }}\right.$ water) value of 0.41 [24]. Intracellular sites are more likely to be the primary inhibition targets of furfural and HMF. In contrast, both 2-furoic acid and furfuryl alcohol have been shown to cause significant membrane leakage $[23,25]$. Furfuryl alcohol also exhibits synergism when in binary combinations with other inhibitors, while 2-furoic acid results in additive toxicity $[23,24]$.

Ethanol production is inhibited in E. coli LYO1 by furfural, suggesting a direct effect on glycotic and/or fermentative enzymes [24]. Glycotic dehydrogenases like alcohol dehydrogenase (ADH) have been indicated as a potential site of inhibition via $\mathrm{NAD}(\mathrm{P}) \mathrm{H}$-dependent aldehyde reduction into the corresponding alcohol [27]. A study performed in vitro has confirmed that acetaldehyde to ethanol conversion was inhibited by both furfural and HMF [91]. Subsequent in vitro enzymatic assays in this study demonstrated that furfural was a substrate for ADH (EC 1.1.1.1), albeit at a five-fold increase in $K_{m}$ and five-fold decrease in $V_{\max }$. In the same study, furfural inhibition on aldehyde dehydrogenase (EC 1.2.1.5) and the pyruvate dehydrogenase complex were investigated and determined to be more significant than $\mathrm{ADH}$, as indicated by more than $80 \%$ activity reduction in the presence of 0.12 $\mathrm{g} / \mathrm{L}$ furfural, whereas ADH activity was only inhibited by $60 \%$. These findings suggest that furfural may detrimentally affect multiple glycotic enzymes essential to central metabolism.

Furfural and HMF have shown cytotoxic characteristics towards both bacteria and yeast [24,92-94]. Furfural is a known dietary mutagen and has been under investigation for direct effects on DNA in the past. A series of studies by Hadi and coworkers confirmed that furfural-DNA interactions occur. Furfural-treated double-stranded DNA led to single-strand breaks after undergoing in vitro incubation with furfural, primarily at sequence sites with three or 
more adenine or thymine bases [28,32]. Later, plasmids treated with furfural were observed to cause either an increase (high furfural concentrations) or decrease (low furfural concentrations) in plasmid size via insertions, duplications, or deletions [30].

\section{Modes of tolerance}

Although furfural damages DNA, cells with necessary DNA repair mechanisms still maintain viability. Despite the mutagenic interaction of furfural with DNA as previously stated, in vivo experimentation suggests the importance of the polA-mediated DNA repair pathway for tolerating scissions caused by furfural [31]. Cells have been observed to repair damaged DNA, reducing the frequency of furfural-induced mutagenic events to that of random mutation found in untreated cultures [95].

Recombinant E. coli has been shown to metabolize furfural into furfuryl alcohol under aerobic conditions [96]. The bioconversion is thought to occur via a NADPHdependent furfural reductase, which is the first of its kind to be reported in the class of alcohol-aldehyde oxidoreductases [97]. In the same study, the furfural reductase showed an increased rate of NADPH oxidation when acting on benzaldehyde compared to furfural, suggesting that it can utilize a variety of aldehydes as substrates.

Conversely, a recent long-course adaptation experiment with ethanologenic E. coli found that furfural tolerance is conferred by silencing certain NADPH-dependent oxioreductases [98]. Genes of special interest in this work were $y q h D$ and $d k g A$, both of which encode gene products with low $K_{m}$ s for NADPH, allowing for biosynthetic reaction competition. Miller et al. [98] propose that competition exists between furfural reduction and biosynthesis by observing that cells initially undergo a lag phase, consistent with decreased biosynthesis, as the NADPH pool is devoted to furfural reduction. The mutant with silenced $y q h D$ and $d k g A$ genes was able to concurrently reduce furfural and grow, providing further support for the proposed claim. YqhD is also reported to play an important role in protecting E. coli from aldehydes derived from lipid-peroxidation via a glutathione-independent, NADPH-dependent reduction mechanism [99]. Interesting to note is that the mutant obtained from this study also overexpressed eight oxioreductases that can use NADPH as an electron donor. For example, the product of one such gene, yajO, is highly specific for utilizing 2-carboxybenzaldehyde as a substrate in comparison to a variety of other aldehydes [100]. Further studies should be performed on these isolated oxioreducatases for a variety of substrates to explore the interplay between them and the detrimental effects of cellular utilization of NADPH for aldehyde reduction because NADH- and NADPHdependent reduction of furan derivatives has proved par- amount for hydrolysate inhibitor tolerance in S. cerevisiae and Pichia stipitis [101-105].

E. coli K12 mutants are also capable of converting furfural to 2-furoic acid, a weak acid that can form at low levels during pretreatment $[106,107]$. This acid inhibits growth at concentrations as low as $0.5 \mathrm{~g} / \mathrm{L}[23,24]$. Interestingly, these E. coli K12 mutants were shown to metabolize 2furoic acid and furfuryl alcohol as sole carbon sources [108]. Isolated mutants from this study revealed beneficial mutations in ato $C$ and $f a d R$, genes related to transcriptional activation and regulation of fatty acid metabolism $[109,110]$. The mechanism relating fatty acid metabolism with furfural metabolism has not yet been determined.

\section{Phenolic compounds}

Hydrolysates can contain up to $30 \%$ lignin content for a variety of feedstocks [83,92]. Major phenolic compounds have carboxyl, formyl, or hydroxyl group functionalities and arise from degradation of lignin during pretreatment. Ketones can also be released during pretreatment, but are not generally considered as primary inhibitors because they occur at low concentrations $(<0.05 \mathrm{~g} / \mathrm{L})$ and are also partially or completely removed with various detoxification treatments [20]. Most of the lignin and its derivatives are insoluble; after dilute acid pretreatment of yellow poplar, no more than $15 \%$ of the total lignin feedstock content was converted to a soluble species $[33,92]$. Concentrations of aromatic monomers after dilute acid washes have been measured at between 0 and $3 \mathrm{~g} / \mathrm{L}$ and include acids, alcohols, and aldehydes [20,111,112]. Due to the number of lignin-derived compounds needing to be analyzed, sequential studies with $E$. coli have been limited. As such, only the most commonly studied compounds are reviewed in this work.

\section{Modes of toxicity}

A series of studies comparing aldehydes, acids, and alcohols appearing in hydrolysate were performed with the ethanologenic E. coli LYO1 [23-25]. In general, the degree of toxicity correlated with the compound's octanol/water partition coefficient, $\log \left(\mathrm{P}_{\text {octanol/water }}\right)$, which is a measure of hydrophobicity. In all studies the phenolics were more toxic than aliphatics or furans with the same functional group. This observation that hydrophobicity was related to membrane damage was only true for the alcohols tested, with the exception of hydroquinone. Aromatic acids caused partial membrane leakage while the aromatic aldehydes caused no significant membrane damage. A synergistic binary combination was observed for guaiacol and methylcatechol, but a less than additive combination was observed for vanillyl alcohol and all lignin-derived alcohols tested (catechol, coniferyl, guaiacol, hydroquinone, and methylcatechol). Vanillin, a phenolic aldehyde, was found to be bacteriostatic and membrane 
active, thus causing partial disruption of $\mathrm{K}^{+}$gradients in $E$. coli MC1022 [113]. This finding is similar to the effect of methylglyoxal on E. coli [114]. Membrane destabilization was experienced by $29 \%$ of the population after treatment with vanillin for 1 hour at over three times the minimum inhibitory concentration, but restored to $13 \%$ when grown overnight [113]. In addition, this study showed that ATP production continues without significant interruption. In previous reports, membrane damage was found to not contribute significantly to toxicity [24]. From these data, hypotheses have been developed stating that other cellular hydrophobic components may be the primary target for inhibition $[24,113]$.

\section{Modes of tolerance}

From the studies conducted on E. coli LYO1, only tolerance to aldehydes benefited from increased inoculum size, suggesting metabolism of the compounds [23-25]. Similar to findings on furan derivatives, microbial metabolism of phenolic aldehydes is supported by previous findings in recombinant $E$. coli, the closely related enteric bacterium Klebsiella pneumonia, and S. cerevisiae [97,115117]. Furthermore, recombinant $E$. coli are capable of converting aromatic aldehydes to their corresponding acids [118]. Non-lignin derived aromatic acids have also been shown to be metabolized as sole carbon sources, similar to observations of furfural and HMF metabolism [108]. Conversion of an aldehyde to carboxylic acid or alcohol is often beneficial for $E$. coli due to the reduced toxicity of the functional group [23-25]. To date, tolerance to phenolic compounds has not been adequately studied for Gram-negative prokaryotes. A recent study on S. cerevisiae identified genes required for vanillin tolerance, but these genes are categorized for chromatin remodeling and vesicle transport functionalities, which does not readily lend itself to application for E. coli [119].

\section{Engineering tolerance}

Engineering tolerance to hydrolysate byproducts is an attractive method for improving lignocellulosic biomass based biofuel production in E. coli. Several methodologies have been used for this purpose. The conventional approach is to perform long-course adaptation studies. This method has been used to generate the ethanologenic E. coli LY01 strain. Over a 3-month period, E. coli KO11 was grown recursively in ethanol-containing media and plated on chloramphenicol-containing solid media (on which large colonies indicated good ethanol production) [120]. The LY01 strain showed 50\% relative growth rate $(\mu)$ at $30 \mathrm{~g} / \mathrm{L}$ ethanol where the parent KO11 showed 50\% relative growth rate $(\mu)$ in $20 \mathrm{~g} / \mathrm{L}$ [24]. The resultant $E$. coli LY01 strain was not only more tolerant to ethanol than KO11, but showed a decreased sensitivity to toxic aldehydes as well [24]. Gonzalez et al. [121] showed expression levels of genes involved in protective osmolytes, antibiotic resistance proteins, and cell envelope components were significantly different in LY01 and KO11. Using chemical mutagens can, over a short period of time, achieve similar results as long-course adaptation. Randomly mutating $E$. coli using nitrosoguanidine mutagenesis has been used to increase the complete inhibition concentration of vanillin from 3 to $4 \mathrm{~g} / \mathrm{L}$ [122].

Genomic library selection is a powerful tool that can discover genes or operons that, with increased copy number, confer a desired phenotype. The advent of DNA microarrays has made it easier to identify these beneficial genes. SCALEs (Scalar Analysis of Library Enrichments), and its predecessor PGTM (Parallel Gene Trait Mapping), have used $E$. coli genomic library selection and microarrays to engineer tolerance to Pine-Sol antibiotic, antimetabolites, 3-hydroxypropionic acid, and naphthol [73,123-126]. Genomic selections employing libraries of heterologous genes have also been used to engineer tolerance. A genomic library of Sphingomonas sp. 14DN61 was used in E. coli to find the PhnN enzyme, which converts aromatic aldehydes, such as vanillin, to their milder corresponding carboxylic acid [118]. Other methods of creating tolerant strains include engineering sigma factors, which alter the transcription of the cell. Global transcription machinery engineering utilizes random mutagenesis of sigma factor genes to create libraries of mutated sigma factors. These mutants are then selected for improved tolerance. As a proof of concept, a $40 \%$ increase in growth rate at $40 \mathrm{~g} / \mathrm{L}$ ethanol tolerance was reported [127]. Also, mutants found after global transcription machinery engineering selection using high levels of acetate $(30 \mathrm{~g} / \mathrm{L})$ increased growth rate $(\mu)$ by a factor of five [128].

Rational designing of E. coli to better cope with toxins in hydrolysate has yielded mixed results. After determining methionine biosynthesis was being inhibited in the presence of acetate, Roe et al. [43] overexpressed the metE gene, which converts homocysteine to methionine, and the glyA gene, which is necessary for $5 \mathrm{~N}$-methyltetrahydrofolate regeneration (a part of methionine synthesis). However, no decrease in acetate sensitivity was found with either clone. Heterologous cloning of potentially beneficial genes has also been attempted. Aldehyde oxidoreductase from a Nocardia species reduces aromatic carboxylic acids to the corresponding aldehydes, which are then natively converted to the milder corresponding alcohol. This gene was cloned in to E. coli, but a 50-fold lower specific activity was seen [129]. When incubated with a cofactor and the Nocardia sp. post-translation enzyme, heterologous expression gave a specific activity 20 -fold higher than before [129]. In another effort, Pseudomonas putida benzaldehyde dehydrogenase was cloned into $E$. coli. Coupled with a NahR reporter system, catalytically active enzyme was selected for using a tet-based host 
[130]. The fungus Coniochaeta ligniaria was found by selection of various microorganisms sampled from soil in media containing furfural and HMF. It was later shown to degrade both furfural and HMF [79]. The genes responsible for such degradation may be attractive metabolic engineering targets. In a novel fermentation strategy, Eiteman et al. [131] propose using E. coli strains designed to be able to use only one substrate as a carbon source. In a two-part fermentation, a strain designed to consume only acetate acts first, then, the detoxified hydrolysate would undergo simultaneous fermentation by a glucose-consuming strain and a xylose-consuming strain $[131,132]$.

\section{Conclusion}

Biofuels production must find cost-effective and sustainable feedstocks. The commercial potential of biofuels largely depends on the abundance and cost of the feedstock. From 2000 to 2007, global biofuel production tripled, but is still only $3 \%$ of the global transportation energy [133]. As this number grows, commercial processes will necessarily rely more heavily upon lignocellulosic biomass. Much work is still required to improve the efficiency of fermentations of biomass hydrolysate to levels cost competitive with fermentation of pure sugar streams. Emphasis should be placed upon not only further reducing the cost of the enzymatic hydrolysis step but also upon better understanding of hydrolysate toxicity mechanisms and methods for engineering tolerance. More specifically, elucidating the modes of action of specific compounds present in hydrolysate will prove critical since the levels of inhibition of various aldehydes and weak acids can vary greatly. It is for this reason that new technologies must emerge in order to more rapidly decipher toxicity and tolerance phenotypes. Once such understanding is generated, processes involving fermentation of lignocelluosic hydrolysates that meet and surpass the productivity of sugar-based bioprocesses will be enabled.

\section{Abbreviations}

ADH: alcohol dehydrogenase; HMF: 5-hydroxymethylfurfural.

\section{Competing interests}

The authors declare that they have no competing interests.

\section{Authors' contributions}

TYM authored the Introduction, Furan derivatives, and Phenolic compounds portions of this manuscript. NRS authored the Organic acids and Engineering tolerance sections and the Conclusions. RTG provided critical review, structural advice, as well as writing and editing.

\section{Acknowledgements}

TYM and NRS are both supported by National Science Foundation Graduate Research Fellowships.

\section{References}

I. Perlack RD, Wright LL, Turhollow AF, Graham RL, Stokes BJ, Erbach DC: Biomass as Feedstock for a Bioenergy and Bioproducts Industry: the Technical Feasability of a Billion-ton Annual Supply. 2005 [http://www.ornl.gov/ webworks/cppr/y200l/rpt/ 123021.pdf]. US Department of Agriculture

2. Directive 2003/30/EC of the European Parliament and of the Council, 8 May 2003, on the Promotion of the Use of Biofuels or Other Renewable Fuels for Transport [http://ec.europa.eu/energy/res/legislation/doc/bio fuels/en final.pdf].

3. Energy Information Administration: International Energy Outlook 2000. [http://www.eia.doe.gov/oiaf/archive/ieo00/index.html].

4. Energy Information Administration: Annual Energy Outlook 2008: With Projections to 2030. [http://www.eia.doe.gov/oiaf/ archive/ieo08/index.html].

5. Energy Information Administration: Short-Term Energy Outlook. [http://www.eia.doe.gov/pub/forecasting/steo/oldsteos/jul08.pdf].

6. New Energy for America 2008 [http://www.barackobama.com/issues/ newenergy/index.php].

7. National Renewable Energy Laboratory: Research Advances: CelIulosic Ethanol 2007. [http://www.nrel.gov/biomass/pdfs/ 40742.pdf].

8. Searchinger T, Heimlich R, Houghton RA, Dong F, Elobeid A, Fabiosa J, Tokgoz S, Hayes D, Yu TH: Use of U.S. croplands for biofuels increases greenhouse gases through emissions from land-use change. Science 2008, 3 1 9:1238-1240.

9. Sanchez J, Junyang J: GAIN Report: China, Peoples Republic of, Bio-Fuels Annual Report. 2008 [http://www.fas.usda.gov/gainfiles/ 200806/I46295020.pdf]. USDA Foreign Agricultural Service

10. Wilson J: GAIN Report: United Kingdom, Bio-Fuels, Biofuels under fire. 2008 [http://www.fas.usda.gov/gainfiles/200807/ |46295|26.pdf]. USDA Foreign Agricultural Service

II. Sanderson K: US biofuels: a field in ferment. Nature 2006 , 444:673-676.

12. Palmqvist E, Hahn-Hagerdal B: Fermentation of lignocellulosic hydrolysates. I: inhibition and detoxification. Bioresour Technol 2000, 74:17-24.

13. Sun $Y$, Cheng !: Hydrolysis of lignocellulosic materials for ethanol production: a review. Bioresour Technol 2002, 83: I-II.

14. Mosier N, Wymanb C, Dalec B, Elanderd R, Lee YY, Holtzapplef M, Ladisch M: Features of promising technologies for pretreatment of lignocellulosic biomass. Bioresour Technol 2005, 96:673-686.

15. Kumar R, Singh S, Singh OV: Bioconversion of lignocellulosic biomass: biochemical and molecular perspectives. J Ind Microbiol Biotechnol 2008, 35:377-391.

16. Niehaus F, Bertoldo C, Kähler M, Antranikian G: Extremophiles as a source of novel enzymes for industrial application. Appl Microbiol Biotechnol I 999, 51:71 I-729.

17. Olsson L, Hahn-Hagerdal B: Fermentation of lignocellulosic hydrolysates for ethanol production. Enzyme Microbial Technol 1996, | 8:3|2-33|.

18. Ulbricht RJ, Northup SJ, Thomas JA: A review of 5-hydroxymethylfurfural (Hmf) in parenteral solutions. Fundam Appl Toxicol 1984, 4:843-853.

19. Dunlop AP: Furfural formation and behavior. Ind Eng Chem 1948, 40:204-209.

20. Larsson S, Reimann A, Nilvebrant N-O, Jönsson LJ: Comparison of different methods for the detoxification of lignocellulose hydrolyzates of spruce. Appl Biochem Biotechnol 1999, 77. 9:91-103.

21. Ranatunga TD, Jervis J, Helm RF, McMillan JD, Wooley RJ: The effect of overliming on the toxicity of dilute acid pretreated lignocellulosics: the role of inorganics, uronic acids and ether-soluble organics. Enzyme Microbial Technol 2000, 27:240-247.

22. Dien BS, Cotta MA, Jeffries TW: Bacteria engineered for fuel ethanol production: current status. Appl Microbiol Biotechnol 2003, 63:258-266.

23. Zaldivar J, Ingram LO: Effect of organic acids on the growth and fermentation of ethanologenic Escherichia coli LYOI. Biotechnol Bioeng 1999, 66:203-210.

24. Zaldivar J, Martinez A, Ingram LO: Effect of selected aldehydes on the growth and fermentation of ethanologenic Escherichia coli. Biotechnol Bioeng 1999, 65:24-33.

25. Zaldivar J, Martinez A, Ingram LO: Effect of alcohol compounds found in hemicellulose hydrolysate on the growth and fer- 
mentation of ethanologenic Escherichia coli. Biotechnol Bioeng 2000, 68:524-530.

26. Jarboe LR, Grabar TB, Yomano LP, Shanmugan KT, Ingram LO: Development of ethanologenic bacteria. Adv Biochem Eng Biotechnol 2007, 1 08:237-26I.

27. Banerjee N, Bhatnagar R, Viswanathan L: Inhibition of glycolysis by furfural in Saccharomyces cerevisiae. Eur J Appl Microbiol Biotechnol 1981, I I:226-228.

28. Hadi SM, Shahabuddin, Rehman A: Specificity of the interaction of furfural with DNA. Mutat Res 1989, 225:101-106.

29. Ingram LO: Adaptation of membrane lipids to alcohols. J Bacteriol 1976, I25:670-678.

30. Khan QA, Hadi SM: Effect of furfural on plasmid DNA. Biochem Mol Biol Int 1993, 29: I I53-II60.

31. Khan QA, Hadi SM: Inactivation and repair of bacteriophage lambda by furfural. Biochem Mol Biol Int 1994, 32:379-385.

32. Shahabuddin, Rahman A, Hadi SM: Reaction of furfural and methylfurfural with DNA: use of single-strand-specific nucleases. Food Chem Toxicol 1991, 29:719-72I.

33. Tucker MP, Farmer JD, Keller FA, Schell DJ, Nguyan QA: Comparison of yellow poplar pretreatment between NREL digester and sunds hydrolyzer. Appl Biochem Biotechnol I998, 70-2:25-35.

34. Aden ARM, Ibsen K, Jechura J, Neeves K, Sheehan J, Wallace B, Montague L, Slayton A, Lukas J: Lignocellulosic Biomass to Ethanol Process Design and Economics Utilizing Co-Current Dilute Acid Prehydrolysis and Enzymatic Hydrolysis for Corn Stover Golden, Colorado: Nationa Renewable Energy Laboratory; 2002.

35. García-Aparicio MP, Ballesteros I, González A, Oliva JM, Ballesteros $M$, Negro MJ: Effect of inhibitors released during steam-explosion pretreatment of barley straw on enzymatic hydrolysis. Appl Biochem Biotechnol 2006, I 29:278-288.

36. Martin C, Alriksson B, Sjöde A, Nilvebrant NO, Jönsson LJ: Dilute sulfuric acid pretreatment of agricultural and agro-industrial residues for ethanol production. Appl Biochem Biotechnol 2007, I 37:339-352.

37. Schmidt AS, Thomsen AB: Optimization of wet oxidation pretreatment of wheat straw. Bioresour Technol 1998, 64:|39-151.

38. Koullas DP, Lois E, Koukios EG: Effect of physical pretreatments on the prepyrolytic behavior of lignocellulosics. Biomass Bioen ergy |99|, I:199-206.

39. Tengborg C, Galbe M, Zacchi G: Reduced inhibition of enzymatic hydrolysis of steam-pretreated softwood. Enzyme Microbial Technol 200I, 28:835-844.

40. Fenske JJ, Hashimoto A, Penner $\mathrm{MH}$ : Relative fermentability of lignocellulosic dilute-acid prehydrolysates - application of a Pichia stipitis-based toxicity assay. Appl Biochem Biotechnol 1998 , 73:145-157.

4l. Tran AV, Chambers RP: Red oak wood derived inhibitors in the ethanol fermentation of xylose by Pichia stipitis Cbs-5776. Biotechnol Lett 1985, 7:84I-845.

42. Roe AJ, McLaggan D, Davidson I, O'Byrne C, Booth IR: Perturbation of anion balance during inhibition of growth of Escherichia coli by weak acids. I Bacteriol 1998, I 80:767-772.

43. Roe AJ, O'Byrne C, McLaggan D, Booth IR: Inhibition of Escherichia coli growth by acetic acid: a problem with methionine biosynthesis and homocysteine toxicity. Microbiology 2002, I 48:2215-2222.

44. Takahashi CM, Takahashi DF, Carvalhal ML, Alterthum F: Effects of acetate on the growth and fermentation performance of Escherichia coli KOI I. Appl Biochem Biotechnol I999, 8I:193-203.

45. Koh BT, Nakashimada U, Pfeiffer M, Yap MGS: Comparison of acetate inhibition on growth of host and recombinant $E$. coli KI 2 strains. Biotechnol Lett 1992, I4: I I I5- I I I8.

46. Luli GW, Strohl WR: Comparison of growth, acetate production, and acetate inhibition of Escherichia coli strains in batch and fed-batch fermentations. Appl Environ Microbiol 1990 56:1004-1011.

47. Nakano K, Rischke M, Sato S, Märkl H: Influence of acetic acid on the growth of Escherichia coli KI2 during high-cell-density cultivation in a dialysis reactor. Appl Microbiol Biotechnol 1997, 48:597-601.

48. Axe D, Bailey JE: Transport of lactate and acetate through the energized cytoplasmic membrane of Escherichia coli. Biotechnol Bioeng 1995, 47:8-19.
49. Walter A, Gutknecht J: Monocarboxylic acid permeation through lipid bilayer membranes. J Membr Biol 1984, 77:255-264.

50. Cherrington CA, Hinton M, Chopra I: Effect of short-chain organic acids on macromolecular synthesis in Escherichia coli. J Appl Bacteriol 1990, 68:69-74.

5I. Sinha RP: Toxicity of organic acids for repair-deficient strains of Escherichia coli. Appl Environ Microbiol I986, 5 I: I364-I366.

52. Cherrington CA, Hinton M, Pearson GR, Chopra I: Inhibition of Escherichia coli KI 2 by short-chain organic acids: lack of evidence for induction of the SOS response. J Appl Bacteriol I991, 70:156- 160.

53. Cherrington CA, Hinton M, Pearson GR, Chopra I: Short-chain organic acids at ph $\mathbf{5 . 0}$ kill Escherichia coli and Salmonella spp. without causing membrane perturbation. J Appl Bacteriol 1991, 70:161-165

54. McLaggan D, Naprstek J, Buurman ET, Epstein W: Interdependence of $\mathrm{K}+$ and glutamate accumulation during osmotic adaptation of Escherichia coli. J Biol Chem 1994, 269: I91 I-I917.

55. Underwood SA, Buszko ML, Shanmugam KT, Ingram LO: Lack of protective osmolytes limits final cell density and volumetric productivity of ethanologenic Escherichia coli KO I l during xylose fermentation. Appl Environ Microbiol 2004, 70:2734-2740.

56. Kroll RG, Booth IR: The relationship between intracellular $\mathbf{p H}$, the $\mathrm{pH}$ gradient and potassium transport in Escherichia coli. Biochem J 1983, 2 | 6:709-7|6.

57. Goodson M, Rowbury RJ: Habituation to normally lethal acidity by prior growth of Escherichia coli at a sub-lethal acid $\mathrm{pH}$ value. Lett Appl Microbiol 1989, 8:77-79.

58. Lin J, Lee IS, Frey J, Slonczewski JL, Foster JW: Comparative analysis of extreme acid survival in Salmonella typhimurium, Shigella flexneri, and Escherichia coli. J Bacteriol 1995, I 77:4097-4 I04.

59. Moreau PL: The lysine decarboxylase CadA protects Escherichia coli starved of phosphate against fermentation acids. J Bacteriol 2007, 189:2249-226I.

60. lyer R, Williams C, Miller C: Arginine-agmatine antiporter in extreme acid resistance in Escherichia coli. | Bacteriol 2003, | 85:6556-656|.

6I. Richard H, Foster JW: Escherichia coli glutamate- and argininedependent acid resistance systems increase internal $\mathrm{pH}$ and reverse transmembrane potential. J Bacteriol 2004, | 86:6032-604|.

62. Castanie-Cornet MP, Penfound TA, Smith D, Elliott JF, Foster JW: Control of acid resistance in Escherichia coli. J Bacteriol 1999 | $81: 3525-3535$.

63. Warnecke T, Gill RT: Organic acid toxicity, tolerance, and production in Escherichia coli biorefining applications. Microb Cell Fact 2005, 4:25

64. Lin J, Smith MP, Chapin KC, Baik HS, Bennett GN, Foster JW: Mechanisms of acid resistance in enterohemorrhagic Escherichio coli. Appl Environ Microbiol 1996, 62:3094-3100.

65. Gong S, Richard H, Foster JW: YjdE (AdiC) is the arginine:agmatine antiporter essential for arginine-dependent acid resistance in Escherichia coli. I Bacteriol 2003, 185:4402-4409.

66. Maurer LM, Yohannes E, Bondurant SS, Radmacher M, Slonczewski JL: pH regulates genes for flagellar motility, catabolism, and oxidative stress in Escherichia coli K-I2. J Bacteriol 2005, I 87:304-319.

67. Schellhorn HE, Stones VL. Regulation of katF and katE in Escherichia coli K-I2 by weak acids. J Bacteriol 1992, | 74:4769-4776.

68. Arnold CN, McElhanon J, Lee A, Leonhart R, Siegele DA: Global analysis of Escherichia coli gene expression during the acetate-induced acid tolerance response. I Bacteriol 200I, 183:2178-2186.

69. Ma Z, Gong S, Richard H, Tucker DL, Conway T, Foster JW: GadE (YhiE) activates glutamate decarboxylase-dependent acid resistance in Escherichia coli K-I2. Mol Microbiol 2003, 49:1309-1320.

70. Ma Z, Richard H, Tucker DL, Conway T, Foster JW: Collaborative regulation of Escherichia coli glutamate-dependent acid resistance by two AraC-like regulators, GadX and GadW (YhiW). J Bacteriol 2002, I 84:700I-7012.

71. Richard H, Foster JW: Sodium regulates Escherichia coli acid resistance, and influences $\mathbf{G a d X}$ - and $\mathbf{G a d W}$-dependent activation of gadE. Microbiology 2007, I 53:3 I54-316I. 
72. Choi SH, Baumler DJ, Kaspar CW: Contribution of dps to acid stress tolerance and oxidative stress tolerance in Escherichia coli OI 57:H7. Appl Environ Microbiol 2000, 66:391 I-3916.

73. Warnecke TE, Lynch MD, Karimpour-Fard A, Sandoval N, Gill RT: A genomics approach to improve the analysis and design of strain selections. Metab Eng 2008, I 0:154- 165.

74. Warnecke T: A genomics approach to improve the analysis and design of strain selections. Metabolic Engineering VII: Health and Sustainability: Puerto Vallarta, Mexico 2008 [http://www.engcon fintl.org/pastconf/08ayfin.pdf]. Engineering Conferences International

75. Larsson S, Palmqvist E, Hahn-Hägerdal B, Tengborg C, Stenberg K, Zacchi G, Nilvebrant N-O: The generation of fermentation inhibitors during dilute acid hydrolysis of softwood. Enzyme Microbial Technol 1999, 24:151-159.

76. Martinez A, Rodriguez ME, Wells ML, York SW, Preston JF, Ingram LO: Detoxification of dilute acid hydrolysates of lignocellulose with lime. Biotechnol Prog 200I, I 7:287-293.

77. Oefner PJ, Lanziner AH, Bonn G, Bobleter O: Quantitative studies on furfural and organic-acid formation during hydrothermal, acidic and alkaline-degradation of deuterium-xylose. Monatshefte Fur Chemie 1992, I 23:547-556.

78. Saha BC: Hemicellulose bioconversion. J Ind Microbiol Biotechnol 2003, 30:279-29I

79. López MJ, Nichols NN, Dien BS, Moreno J, Bothast RJ: Isolation of microorganisms for biological detoxification of lignocelluIosic hydrolysates. Appl Microbiol Biotechnol 2004, 64: | 25- I 3 I.

80. Saha BC, Iten LB, Cotta MA, Wu YV: Dilute acid pretreatment, enzymatic saccharification, and fermentation of rice hulls to ethanol. Biotechnol Prog 2005, 2 I:816-822.

8I. Saha BC, Itena LB, Cottaa MA, Wu YV: Dilute acid pretreatment, enzymatic saccharification and fermentation of wheat straw to ethanol. Process Biochem 2005, 40:3693-3700.

82. Sierra R, Smith A, Granda C, Holtzapple MT: Producing fuels and chemicals from lignocellulosic biomass. Chem Eng Prog 2008, 104:SI0-SI7.

83. Yat SC, Berger A, Shonnard DR: Kinetic characterization for dilute sulfuric acid hydrolysis of timber varieties and switchgrass. Bioresour Technol 2008, 99:3855-3863.

84. Haselkorn R, Doty P: The reaction of formaldehyde with polynucleotides. I Biol Chem I 96I, 236:2738-2745.

85. Sambrook J, Russell DW: Molecular Cloning: A Laboratory Manual Volume I. 3rd edition. Cold Spring Harbor, NY: Cold Spring Harbor Laboratory Press; 200I.

86. Kummerle N, Feucht HH, Kaulfers PM: Plasmid-mediated formaldehyde resistance in Escherichia coli: characterization of resistance gene. Antimicrob Agents Chemother 1996, 40:2276-2279.

87. Gonzalez CF, Proudfoot M, Brown G, Korniyenko Y, Mori H, Savchenko AV, Yakunin AF: Molecular basis of formaldehyde detoxification. Characterization of two S-formylglutathione hydrolases from Escherichia coli, FrmB and YeiG. J Biol Chem 2006, 281: |45|4-|4522

88. Azachi M, Henis $Y$, Shapira R, Oren A: The role of the outer membrane in formaldehyde tolerance in Escherichia coli VU3695 and Halomonas sp. MAC. Microbiology 1996, | 42: | 249- | 254 .

89. Egyud LG, Szent-Gyorgyi A: On the regulation of cell division. Proc Natl Acad Sci USA 1966, 56:203-207.

90. Egyud LG, Szent-Gyorgyi A: Cell division, $\mathbf{S H}$, ketoaldehydes, and cancer. Proc Natl Acad Sci USA 1966, 55:388-393.

91. Modig T, Liden G, Taherzadeh MJ: Inhibition effects of furfural on alcohol dehydrogenase, aldehyde dehydrogenase and pyruvate dehydrogenase. Biochem / 2002, 363:769-776.

92. Ranatunga TD, Jervis J, Helm RF, McMillan JD, Hatzis C: Identification of inhibitory components toxic toward Zymomonas mobilis CP4(pZB5) xylose fermentation. Appl Biochem Biotechnol 1997, 67:185-198.

93. Taherzadeh MJ, Gustafsson L, Niklasson C, Lidén G: Physiological effects of 5-hydroxymethylfurfural on Saccharomyces cerevisiae. Appl Microbiol Biotechnol 2000, 53:701-708.

94. Taherzadeh MJ, Gustafsson L, Niklasson C, Lidén G: Inhibition effects of furfural on aerobic batch cultivation of Saccharomyces cerevisiae growing on ethanol and/or acetic acid. J Biosci Bioeng 2000, 90:374-380.

95. Khan QA, Shamsi FA, Hadi SM: Mutagenicity of furfural in plasmid DNA. Cancer Lett 1995, 89:95-99.
96. Gutiérrez T, Buszko ML, Ingram LO, Preston JF: Reduction of furfural to furfuryl alcohol by ethanologenic strains of bacteria and its effect on ethanol production from xylose. Appl Biochem Biotechnol 2002, 98-I 00:327-340.

97. Gutierrez T, Ingram LO, Preston JF: Purification and characterization of a furfural reductase (FFR) from Escherichia col strain LYOI - an enzyme important in the detoxification of furfural during ethanol production. J Biotechnol 2006, | 2 | : | 54- | 64.

98. Miller EN, Jarboe LR, Yomano LP, York SW, Shanmugam KT, Ingram LO: Silencing of NADPH-dependent oxidoreductases (yqhD and dkgA) in furfural-resistant ethanologenic Escherichia coli. Appl Environ Microbiol 2009, 75:431 5-4323.

99. Pérez JM, Arenas FA, Pradenas GA, Sandoval JM, Vásquez CC: Escherichia coli YqhD exhibits aldehyde reductase activity and protects from the harmful effect of lipid peroxidationderived aldehydes. J Biol Chem 2008, 283:7346-7353.

100. Ko J, Kim I, Yoo S, Min B, Kim K, Park C: Conversion of methylglyoxal to acetol by Escherichia coli aldo-keto reductases. J Bacteriol 2005, I 87:5782-5789.

I0I. Modig T, Almeida JR, Gorwa-Grauslund MF, Lidén G: Variability of the response of Saccharomyces cerevisiae strains to lignocellulose hydrolysate. Biotechnol Bioeng 2008, 1 00:423-429.

102. Liu ZL, Moon J, Andersh BJ, Slininger PJ, Weber S: Multiple genemediated NAD(P)H-dependent aldehyde reduction is a mechanism of in situ detoxification of furfural and 5 hydroxymethylfurfural by Saccharomyces cerevisiae. Appl Microbiol Biotechnol 2008, 8 I:743-753.

103. Laadan B, Almeida JR, Rådström P, Hahn-Hägerdal B, Gorwa-Grauslund $M$ : Identification of an NADH-dependent 5hydroxymethylfurfural-reducing alcohol dehydrogenase in Saccharomyces cerevisiae. Yeast 2008, 25:|9|-|98.

104. Almeida JR, Röder A, Modig T, Laadan B, Lidén G, Gorwa-Grauslund MF: NADH- vs NADPH-coupled reduction of 5-hydroxymethyl furfural (HMF) and its implications on product distribution in Saccharomyces cerevisiae. Appl Microbiol Biotechnol 2008 , 78:939-945.

105. Almeida JR, Modig T, Röder A, Lidén G, Gorwa-Grauslund MF: Pichia stipitis xylose reductase helps detoxifying lignocellulosic hydrolysate by reducing 5-hydroxymethyl-furfural (HMF). Biotechnol Biofuels 2008, I:I2.

106. Wang P, Brenchley JE, Humphrey AE: Screening microorganisms for utilization of furfural and possible intermediates in its degradative pathway. Biotechnol Lett 1994, 16:977-982.

107. Klinke HB, Olsson L, Thomsen AB, Ahring BK: Potential inhibitors from wet oxidation of wheat straw and their effect on ethanol production of Saccharomyces cerevisiae: Wet oxidation and fermentation by yeast. Biotechnol Bioeng 2003, 81:738-747.

108. Abdulrashid N, Clark DP: Isolation and genetic-analysis of mutations allowing the degradation of furans and thiophenes by Escherichia coli. J Bacteriol |987, | 69:|267-|27|.

109. Jenkins LS, Nunn WD: Regulation of the ato operon by the atoC gene in Escherichia coli. | Bacteriol 1987, 169:2096-2102.

I I 0 . Marrakchi H, Zhang YM, Rock CO: Mechanistic diversity and regulation of type II fatty acid synthesis. Biochem Soc Trans 2002 , 30:1050-1055.

I I I. Martinez A, Rodriguez ME, York SW, Preston JF, Ingram LO: Effects of $\mathrm{Ca}(\mathrm{OH})(2)$ treatments ("overliming") on the composition and toxicity of bagasse hemicellulose hydrolysates. Biotechnol Bioeng 2000, 69:526-536.

I I2. Fenske J], Griffin DA, Penner MH: Comparison of aromatic monomers in lignocellulosic biomass prehydrolysates. J Ind Microbiol Biotechnol 1998, 20:364-368.

[13. Fitzgerald DJ, Stratford M, Gasson MJ, Ueckert J, Bos A, Narbad A: Mode of antimicrobial action of vanillin against Escherichia coli, Lactobacillus plantarum and Listeria innocua. J Appl Microbiol 2004, 97: I04-II3.

I 14. Kalapos MP: Methylglyoxal in living organisms: chemistry, biochemistry, toxicology and biological implications. Toxicol Lett 1999, II 0:145-175.

I I5. Mee B, Kelleher D, Frias J, Malone R, Tipton KF, Henehan GT, Windle $H$ J: Characterization of cinnamyl alcohol dehydrogenase of Helicobacter pylori. An aldehyde dismutating enzyme. FEBS 2005, 272: 1255-1264. 
I 16. Nishikawa NK, Sutcliffe R, Saddler JN: The influence of lignin degradation products on xylose fermentation by Klebsiella pneumoniae. Appl Microbiol Biotechnol 1988, 27:549-552.

1 17. Fitzgerald DJ, Stratford M, Narbad A: Analysis of the inhibition of food spoilage yeasts by vanillin. Int J Food Microbiol 2003, 86: $113-122$.

I I8. Peng X, Shindo K, Kanoh K, Inomata Y, Choi SK, Misawa N: Characterization of Sphingomonas aldehyde dehydrogenase catalyzing the conversion of various aromatic aldehydes to their carboxylic acids. Appl Microbiol Biotechnol 2005, 69:|4|-I50.

1 19. Endo A, Nakamura T, Ando A, Tokuyasu K, Shima J: Genome-wide screening of the genes required for tolerance to vanillin, which is a potential inhibitor of bioethanol fermentation, in Saccharomyces cerevisiae. Biotechnol Biofuels 2008, I:3.

120. Yomano LP, York SW, Ingram LO: Isolation and characterization of ethanol-tolerant mutants of Escherichia coli KO I I for fuel ethanol production. J Ind Microbiol Biotechnol 1998, 20:132-138.

I21. Gonzalez R, Tao H, Purvis JE, York SW, Shanmugam KT, Ingram LO: Gene array-based identification of changes that contribute to ethanol tolerance in ethanologenic Escherichia coli: comparison of KO I I (parent) to LYO I (resistant mutant). Biotechnol Prog 2003, 19:612-623.

122. Yoon SH, Lee EG, Das A, Lee SH, Li C, Ryu HK, Choi MS, Seo WT, Kim SW: Enhanced vanillin production from recombinant $E$. coli using NTG mutagenesis and adsorbent resin. Biotechnol Prog 2007, 23: I |43-I |48.

123. Bonomo J, Warnecke T, Hume P, Marizcurrena A, Gill RT: A comparative study of metabolic engineering anti-metabolite tolerance in Escherichia coli. Metab Eng 2006, 8:227-239.

124. Gill RT, Wildt S, Yang YT, Ziesman S, Stephanopoulos G: Genomewide screening for trait conferring genes using DNA microarrays. Proc Natl Acad Sci USA 2002, 99:7033-7038.

125. Lynch MD, Warnecke T, Gill RT: SCALEs: multiscale analysis of library enrichment. Nat Methods 2007, 4:87-93.

126. Gall S, Lynch MD, Sandoval NR, Gill RT: Parallel mapping of genotypes to phenotypes contributing to overall biological fitness. Metab Eng 2008, I 0:382-393.

127. Alper H, Stephanopoulos G: Global transcription machinery engineering: a new approach for improving cellular phenotype. Metab Eng 2007, 9:258-267.

128. Alper H, Stephanopoulos G: Global Transcription Machinery Engineering (Application) US Patent and Trademark Office; 2005

129. Venkitasubramanian P, Daniels L, Rosazza JPN: Reduction of carboxylic acids by Nocardia aldehyde oxidoreductase requires a phosphopantetheinylated enzyme. I Biol Chem 2007, 282:478-485.

130. van Sint Fiet S, van Beilen JB, Witholt B: Selection of biocatalysts for chemical synthesis. Proc Natl Acad Sci USA 2006, 103:1693-1698.

131. Eiteman MA, Lee SA, Altman E: A co-fermentation strategy to consume sugar mixtures effectively. J Biol Eng 2008, 2:3.

132. Eiteman MA, Lakshmanaswamy A, Reilly KC, Altman E: Substrate selective uptake to remove acetate and convert sugar mixtures. 30th Symposium on Biotechnology for Fuels and Chemicals: New Oreans, LA 2008 [http://www.simhq.org/meetings/30symp/ 30SympProgramFront.pdf.

133. Coyle W: The Future of Biofuels: A Global Perspective. 2007 [http://www.ers.usda.gov/AmberWaves/november07/features/biofu els.htm]. USDA Economic Research Service
Publish with Biomed Central and every scientist can read your work free of charge

"BioMed Central will be the most significant development for disseminating the results of biomedical research in our lifetime. "

Sir Paul Nurse, Cancer Research UK

Your research papers will be:

- available free of charge to the entire biomedical community

- peer reviewed and published immediately upon acceptance

- cited in PubMed and archived on PubMed Central

- yours - you keep the copyright

Submit your manuscript here:

http://www.biomedcentral.com/info/publishing_adv.asp
BioMedcentral 